\title{
Effect of Feeding Level Pre- and Post-Puberty and Body Weight at First Calving on Growth, Milk Production, and Fertility in Grazing Dairy Cows
}

\author{
K. A. Macdonald, J. W. Penno, A. M. Bryant, and J. R. Roche \\ Dexcel, Hamilton, New Zealand
}

\begin{abstract}
The effect of feeding to achieve differential growth rates in Holstein-Friesian $(\mathrm{HF} ; \mathrm{n}=259)$ and Jersey $(\mathrm{n}=$ 430) heifers on time to puberty and first lactation milk production was investigated in a $3 \times 2$ factorial design. Holstein-Friesian and Jersey calves were reared to achieve a BW of 100 and $80 \mathrm{~kg}$, respectively, at $100 \mathrm{~d}$. At target weight, all calves were randomly allocated to one of 3 feeding treatments to achieve different growth rates. Holstein-Friesian and Jersey calves were fed fresh pasture to achieve average daily growth rates of $0.77,0.53$, or $0.37 \mathrm{~kg}$ of BW/d (HF) and $0.61,0.48$, or 0.30 $\mathrm{kg}$ of BW/d (Jersey), respectively. Period 1 (prepubertal) was imposed until HF and Jersey treatment groups averaged 200 and $165 \mathrm{~kg}$ of BW, respectively. Following period $1, \mathrm{HF}$ and Jersey calves from each treatment group were randomly allocated to one of 2 feeding treatments to achieve average daily growth rates of 0.69 or $0.49 \mathrm{~kg}$ of BW/d (HF) and 0.58 and $0.43 \mathrm{~kg}$ of BW/d (Jersey), respectively. Period 2 (postpubertal) was imposed until $22 \mathrm{mo}$, when heifers were returned to their farms of origin. Body weight, body condition score, height, heart girth circumference (HGC), milk production, and fertility-related data were collected until the end of the third lactation. Time to reach puberty was negatively associated with level of feeding, and heifers attained puberty at the same BW $(251 \pm 25.4$ and 180 $\pm 24.0 \mathrm{~kg}$ for HF and Jersey heifers, respectively). Heifers on high feed allowances during periods 1 and 2 were heavier, taller, and had greater HGC than their slower grown counterparts until 39 mo of age when height and HGC measurements stopped. Body weight differences remained until $51 \mathrm{mo}$, when measurements ceased. High feed allowance during period 1 (prepubertal) did not affect milk production during the first 2 lactations, but did reduce milk production in lactation 3 . It is possible that the expected negative effect of accelerated prepubertal growth was masked by greater calving BW, as BW-corrected milk yield declined in both breeds with
\end{abstract}

Received October 14, 2004.

Accepted May 25, 2005.

Corresponding author: J. Roche; e-mail: john.roche@dexcel.co.nz. increasing prepubertal feed allowance. Growth rate during period 2 was positively correlated with first lactation milk production. Milk yield increased 7\% in first lactation heifers on the high feed allowance, which resulted in higher growth rate during period 2. Milk production during subsequent lactations was not affected. Results suggest that accelerated prepubertal growth may reduce mammary development in grazing dairy cows, but this does not affect milk production in early lactations because of superior size. Body weight at calving and postpubertal growth rate management are important in first lactation milk production, but do not affect milk production in subsequent lactations.

(Key words: heifer, body weight, milk production, pasture)

Abbreviation key: CIDR = controlled internal drugreleasing device, $\mathbf{H 1}=$ high growth rate during period 1 , H2 = high growth rate during period 2, HF = HolsteinFriesian, HGC = heart girth circumference, $\mathbf{L 1}=$ low growth rate during period $1, \mathbf{L} 2=$ low growth rate during period 2, M1 = medium growth rate during period 1 , PSM = planned start of mating.

\section{INTRODUCTION}

Heifer growth rate and BW at first calving are regarded as important benchmarks in dairy farm management (Sejrsen and Purup, 1997; NRC, 2001). Increased growth rate can reduce the time the heifer spends in a nonproductive state (Capuco et al., 1995; Sejrsen and Purup, 1997), but excessive prepubertal growth rates have been linked to reduced milk production (Harrison et al., 1983; Sejrsen et al., 1983; Ingvartsen et al., 1988; Sejrsen and Purup, 1997). In addition, recommendations on optimum first-calving BW vary widely. In high concentrate intensive feeding systems, it is recommended that Holstein-Friesian (HF) cows achieve 540 to $650 \mathrm{~kg}$ of BW before first calving (Keown and Everett, 1986; Heinrichs, 1993; Hoffman, 1997); a more modest first-calving BW is accepted in pasturebased systems (490 to $550 \mathrm{~kg}$; McLean and Freeman, 1996; Holmes et al., 2002).

Establishing the optimum BW at first calving for different milk production systems is important (Lean, 
1994). As a consequence of improvements in genetics for milk production, current recommendations for firstcalving BW in grazing dairy heifers may require revision (McLean and Freeman, 1996). In recent decades, the search for a more efficient dairy cow has led to widespread use of North American and Dutch HF genetics in pasture-based systems (Buckley et al., 2000; Harris and Kolver, 2001), and previous recommendations for first-calving grazing dairy cows may no longer be appropriate.

If current genetics require larger first-calving cows in pasture-based systems, heifers will be required to achieve faster growth rates to maintain age at first calving, an essential factor in seasonal milk production. Increased prepubertal growth rates have been implicated in reduced mammary parenchymal development (Capuco et al., 1995; Meyer et al., 2004), but there are inconsistencies in the literature on the effect of elevated prepubertal BW gain on milk production. For example, Van der Waaij et al. (1997), after analyzing the genetic and phenotypic correlations amoung BW at 9, 15, and 21 mo and lactation yields from 2365 mixed breed dairy cows, reported a $6.7-\mathrm{kg}$ increase in milk production for each $1 \mathrm{~kg}$ of BW at $15 \mathrm{mo}$. However, on average, cows in their study weighed $370 \mathrm{~kg}$ at $21 \mathrm{mo}$, suggesting that prepubertal growth rate was unlikely to be high enough to illicit a negative response. Nevertheless, Van Amburgh et al. (1998) found no effect of prepubertal feeding when he corrected for BW differences that occurred after puberty. Pirlo et al. (1997) found no difference in milk production in heifers reared to achieve either 0.6 or $0.8 \mathrm{~kg} / \mathrm{d}$ before puberty, and Carson et al. (2000) found no effect of prepubertal growth rate ( 0.70 vs. 1.05 $\mathrm{kg} / \mathrm{d}$ ) on milk production. However, numerous studies reported in the literature do not agree (Foldager and Sejrsen, 1987; Ingvartsen et al., 1988; Lammers et al., 1999; Radcliff et al., 2000), all reporting significant negative effects of prepubertal growth rate on milk production.

The reason for the inconsistencies in published research is unclear. Although it is clear that mammary parenchymal development is retarded by the shorter period to puberty in rapidly reared heifers (Capuco et al., 1995; Meyer et al., 2004), this may not necessarily result in reduced production, particularly in grazing situations where the cows' genetic potential to produce milk is rarely exploited. Similarly, increased BW at calving is presumed to increase a heifer's potential DMI. However, very few experiments have been undertaken to define the relationship between prepubertal growth rate or BW at first calving and subsequent milk production for pasture-based dairy cows, where potential DMI and, hence, milk production may be limited by time available for grazing (Kolver et al., 2002; Thorne et al., 2003).

The objective of this study was to measure the longterm effect of feeding to achieve different heifer growth rates before and after $200 \mathrm{~kg}$ of BW (HF) or $160 \mathrm{~kg}$ of BW (Jersey) on cow BW at first calving and subsequent growth, milk production, reproductive performance, and longevity of HF and Jersey heifers in a pasturebased system following their return to commercial dairy farms.

\section{MATERIALS AND METHODS}

This experiment was undertaken at Dexcel (Hamilton, New Zealand; latitude, $37^{\circ} 47^{\prime} \mathrm{S}$; longitude, $175^{\circ}$ $19^{\prime} \mathrm{E}$; $40 \mathrm{~m}$ above sea level) and on 10 commercial dairy farms within a $30-\mathrm{km}$ radius. Holstein-Friesian and Jersey calves $(<7 \mathrm{~d}$ of age) were sourced and fed to grow at different pre- and postpubertal growth rates in a $3 \times 2$ factorial design before being returned to their farm of origin at 22 mo of age. Physical measurements and milk production data were recorded for the first 3 lactations.

\section{Experimental Design and Treatments}

Between July 1991 and August 1992, and between July 1993 and August 1994, respectively, $245 \mathrm{HF}$ and 400 Jersey heifer calves were collected from 10 commercial dairy farms (5 HF farms and 5 Jersey farms; $24 \mathrm{HF}$ and 40 Jersey calves/yr per farm). Calves were collected from their respective farms at $4 \mathrm{~d}$ of age and were transported to Dexcel's Grazing Unit research farm (Hamilton, New Zealand). In addition, surplus calves from a Dexcel research farm (14 HF and 30 Jersey) were added to the groups as potential spare animals. Mean birth date was August 4 and 5 for the HF and Jersey calves, respectively. Mean $( \pm \mathrm{SD})$ arrival BW was $37 \pm 4.1$ and $29 \pm 4.3 \mathrm{~kg}$ for the $\mathrm{HF}$ and Jersey calves respectively.

Calves were reared in groups of 10 to achieve a target BW of $100 \pm 10.5 \mathrm{~kg}$ (HF) and $80 \pm 9.5$ (Jersey) kg at $100 \pm 10.6 \mathrm{~d}$ of age. To achieve this, all calves were fed $2 \mathrm{~L}$ of whole milk twice daily until approximately $21 \mathrm{~d}$ of age; thereafter, calves received 6 and $5 \mathrm{~L} / \mathrm{d}$ in one feed, for HF and Jersey calves, respectively. At $7 \mathrm{~d}$, calves were offered dry concentrate feed (21\% protein), and at $14 \mathrm{~d}$, they were offered unrestricted access to pasture.

Period 1. At target weight (group average), calves were randomly allocated to one of 3 feeding allowances to achieve projected BW gain targets. Treatments were balanced for BW, BW gain during the period from arrival at Dexcel to the start of period 1, farm of origin, 
sire, ancestral breeding index, and age. HolsteinFriesian and Jersey calves were fed to achieve average daily growth rates of 0.80 and $0.65 \mathrm{~kg}$ of BW/d [high growth rate during period 1 (H1)], 0.60 and $0.50 \mathrm{~kg}$ of BW/d [medium growth rate during period 1 (M1)], or 0.40 and $0.35 \mathrm{~kg}$ of BW/d [low growth rate during period 1 (L1)], respectively. Period 1 was imposed until HF and Jersey heifers averaged 200 and $165 \mathrm{~kg}$ of BW, respectively, and lasted for 135, 200, and $267 \mathrm{~d}$ and 140,176 , and $267 \mathrm{~d}$, respectively, for the H1, M1, and L1 HF and Jersey groups, respectively. These weights were chosen before the beginning of the experiment as approximate weights at which puberty would be reached in both breeds in pasture-based systems.

Period 2. Following period 1, calves from each treatment group were randomly allocated to one of 2 feeding treatments to achieve different growth rates. Again, treatment groups were balanced for BW, BW gain during the period from arrival at Dexcel to the start of period 1, BW gain during period 1, farm of origin, sire, ancestral breeding index, and age. Holstein-Friesian and Jersey calves were fed to achieve average daily growth rates of 0.70 and $0.60 \mathrm{~kg}$ of BW/d [high growth rate during period $2(\mathbf{H 2})]$ or 0.50 and $0.40 \mathrm{~kg}$ of BW/ $\mathrm{d}$ [low growth rate during period $2(\mathbf{L 2})] \mathrm{kg} \mathrm{BW} / \mathrm{d}$, respectively. Period 2 was imposed until 22 mo, when heifers were returned to their farms of origin.

Pregnant heifers were returned to their farms of origin at $665 \pm 9.9 \mathrm{~d}$ of age $(663 \pm 5.9$ and $666 \pm 11.4 \mathrm{~d}$ for $\mathrm{HF}$ and Jersey, respectively). The growth rate combinations imposed in periods 1 and 2 resulted in 6 distinct treatment groups when heifers were returned to their farm of origin: high-high (H1,H2), high-low (H1,L2), medium-high (M1,H2), medium-low (M1,L2), low-high (L1,H2) and low-low (L1,L2).

\section{Feed Management}

Pasture offered was predominantly perennial ryegrass (Lolium perenne L.) and white clover (Trifolium repens), with $<20 \%$ weeds and other grasses (Dactylis glomerata; Poa species). Each treatment group was grazed separately in 0.4-ha paddocks, and a different pasture area was allocated to adjust stocking density (animals/ha per d), thereby achieving a range of heifer DMI and growth rates. It becomes increasingly difficult for dairy stock to graze pasture closer to ground level. Therefore, low postgrazing pasture residuals can be used to restrict DMI in grazing experiments. Offering different grazing area allocations, as was done in the current experiment, facilitates different heifer DMI without confounding factors such as time at pasture or climatic influences.
During the treatment periods, the animals were allocated fresh pasture each day. Body weight was measured weekly up to approximately $400 \mathrm{~d}$ and was measured biweekly until the end of period 2 (EP2). Pasture allowance was adjusted on the basis of these measurements to ensure that desired BW gains were achieved.

Period 1. Pregrazing pasture mass did not differ between treatments and averaged $3188 \pm 651$ and 3184 $\pm 451 \mathrm{~kg}$ of $\mathrm{DM} / \mathrm{ha}$ for $\mathrm{HF}$ and Jersey, respectively. Postgrazing residual pasture mass increased $(P<0.001)$ linearly with pasture allocation $(2388 \pm 727,1934 \pm$ 634 , and $1579 \pm 634 \mathrm{~kg}$ of DM/ha for HF on H1, M1 and L1, respectively, and $2406 \pm 544,2062 \pm 567$, and $1364 \pm 633 \mathrm{~kg}$ of DM/ha for Jerseys on H1, M1, and L1, respectively).

Period 2. Pregrazing pasture mass was higher $(P<$ $0.001)$ for HF heifers than for Jerseys (3199 \pm 651 and $2729 \pm 589 \mathrm{~kg}$ of $\mathrm{DM} / \mathrm{ha}$, respectively), but not across feed allocation treatments. Postgrazing residual pasture mass was higher $(P<0.001)$ in the high feed allowance treatments $(1909 \pm 663,1520 \pm 535,1696 \pm 627$, $1459 \pm 454,1526 \pm 462$, and $1302 \pm 683 \mathrm{~kg}$ of DM/ha for HF heifers on H1H2, H1L2, M1H2, M1L2, L1H2, and L1L2, respectively, and $1779 \pm 560,1267 \pm 406$, $1624 \pm 558,1071 \pm 256,1445 \pm 481$, and $924 \pm 196 \mathrm{~kg}$ of DM/ha for Jersey heifers on H1H2, H1L2, M1H2, M1L2, L1H2, and L1L2, respectively).

\section{Animal Management}

Health. Calves were treated with either a benzimidazole- or levamisole-based drench every $3 \mathrm{wk}$ from weaning to $7 \mathrm{mo}$ and thereafter at $6 \mathrm{wk}$ intervals to control internal parasites. At the start of their first winter and prior to return to their farms, all heifers were treated with an avermectin-based pour-on product for parasite control. They were vaccinated for leptospirosis (Leptovoid 3; Schering-Plough, Coopers Animal Health, Wellington, New Zealand) 3 wk prior to mating and before return to their farms. Zinc sulfate (8 $\mathrm{g}$ of $\mathrm{ZnSO}_{4} \cdot 7 \mathrm{H}_{2} \mathrm{O} / \mathrm{kg}$ of $\mathrm{BW}$ ) was added to their drinking water via a Peta dispenser (Peta Enterprises, Hamilton, New Zealand) during periods of increased vulnerability to facial eczema (Anon, 2004), as determined by fungal spore counts. Each year, several heifers were affected by endophyte-related ryegrass staggers. When severe enough for heifers to become recumbent, they were removed from pasture and fed pasture silage until symptoms disappeared, at which time they were returned to their group.

Puberty and reproduction. Heifers were continually monitored for signs of estrus activity and deemed to reach puberty when first standing estrus was recorded. 
Because of the requirement to calve heifers seasonally, at approximately 15 mo of age, estrus was synchronized for all animals using an intravaginal controlled internal drug-releasing insert (CIDR; InterAg, Hamilton, New Zealand) according to the Genermate program (Cliff et al., 1995). This allowed for a planned start of mating (PSM) on October 20. A CIDR (a plastic device impregnated with $1.9 \mathrm{~g}$ of progesterone and containing a capsule of $10 \mathrm{mg}$ of estradiol) was inserted into the candidate animal's vagina to release progesterone for $10 \mathrm{~d}$ at a controlled rate. Prostaglandin $\mathrm{F}_{2 \alpha}(250 \mu \mathrm{g}$ of Cloprestenol and $1 \mathrm{~mL}$ of Estrumate; Mallinkrodt, Upper Hutt, New Zealand) was administered via injection on d 6 of CIDR treatment. All yearlings were artificially inseminated when visually identified in estrus. Following $16 \mathrm{~d}$ of estrous detection, CIDR were re-inserted into each yearling for $5 \mathrm{~d}$. On detection of estrus following CIDR removal, remaining heifers were inseminated. After $2 \mathrm{~d}$ of estrous detection and insemination, bulls were introduced to the herds for $6.5 \mathrm{wk}$ (10-wk breeding period). Pregnancy from the first insemination was determined by manual palpation at $\mathrm{d} 33$ following first insemination. There were 2 further pregnancy diagnoses approximately 56 and $220 \mathrm{~d}$ after PSM.

\section{On-Farm Management}

All farms were pasture based, and herd size ranged from 225 to 350 cows. Stocking rate was approximately 2.7 and 3.2 cows/ha for HF and Jersey, respectively. On each farm, cows were rotationally grazed as one herd, similar to the method described by Roche et al. (2002). Briefly, cows had access to approximately 30 paddocks (defined grazing area) on each farm, and these paddocks were grazed in a rotational order. As a result, lactating cows had access to a fresh allocation of pasture twice daily and only returned to the same area when a minimum of 2 leaves had appeared on the majority $(>66 \%)$ of perennial ryegrass tillers. During the nonlactation period, cows received a new allocation of pasture once daily. The pastures were predominantly perennial ryegrass and white clover and were typical of the region.

As previously outlined, additional animals were reared to ensure numbers of animals returned to farms were similar to numbers acquired as calves (i.e., zero wastage). This allowed replacement of a treatment animal that died or failed to conceive.

During the first 2 lactations, the farmers were only allowed to cull treatment cows for health reasons or failure to conceive.

\section{Measurements}

During periods 1 and 2, pre- and postgrazing pasture yields were visually assessed as outlined by Roche et al. (2002). One assessor was calibrated weekly through cutting a range of pasture yields that were representative of pre- and postgrazing yields (O'Donovan et al., 2002).

At $7 \mathrm{~d}$ of age, BW, heart girth circumference (HGC) and wither height of calves were measured. Calf BW was measured weekly until approximately $400 \mathrm{~d}$ and subsequently every other week until heifers were returned to their farm of origin. At the end of periods 1 and 2, BW, BCS, HGC, and wither height were measured. Body condition score was measured on a 10-point scale, where $1=$ emaciated to $10=$ obese (Macdonald and Roche, 2004). These scores were then converted to the 5-point scale of Wildman et al. (1982), using the regression equation generated by Roche et al. (2004; $\mathrm{US}=1.5+0.32$ New Zealand).

Body weight, BCS, HGC, and wither height were measured on farm at 27, 30, 40, and $43 \mathrm{mo}$ of age. During the first 2 lactations, milk yields (Tru-Test milk meter system; Palmerston North, New Zealand) and fat and protein percentage (FT120; Foss Electric, Hillerød, Denmark) were determined on individual p.m. and a.m. aliquot samples collected on $1 \mathrm{~d}$ each month. In the third lactation, individual milk yields and composition were recorded on $1 \mathrm{~d}$ every other month.

\section{Calculations and Statistical Analyses}

As all heifers were returned to their farm of origin at 22 mo, individual cow BW at calving and calf birth weight could not be measured. However, to compare the results of the current study with previously published values, precalving heifer BW was deemed to be necessary. Precalving BW was calculated using BW at 22 mo and published regression equations of fetal, placental, and uterine growth (Prior and Laster, 1979), assuming the calf birth weight was equal to the birth weight of the dam, which had been recorded at the beginning of the study.

There is potential for calving BW to influence nutrient intake and utilization during lactation. Although these were likely to be treatment effects (Van Amburgh et al., 1998), milk production data are also presented and are adjusted for BW early in the respective lactation. This was done by including the relevant BW (BW at 60 DIM) at the beginning of each season as a covariate in the analysis.

All data were analyzed as a factorial design using the statistical procedures of Genstat V (1997) with cows as the experimental unit. The model included fixed effects for feeding level (i.e., average daily gain) during period 1 and 2 and their interaction, farm, and year. Data for HF and Jersey were analyzed separately. 
Monthly milk yields and milk component yields were summed to calculate annual yields. These values were used to calculate average fat and protein concentrations for the lactation. Milk yield and composition for the total lactation and average fat and protein concentrations were then analyzed using linear models (Genstat V, 1997). Proportions and percentages (e.g., percent cycling, conception rate, longevity) were analyzed using generalized linear models with binomial error distribution.

\section{RESULTS AND DISCUSSION}

All but 4 calves survived the imposed treatments and were returned to their farm of origin. Of the 4 that were removed, 2 died of bloat, one died from ryegrass staggers, and one broke her leg. A further 56 heifers were culled because of failure to conceive during the required mating period. Six hundred twenty-nine heifers calved (236 HF and 393 Jersey). Of the heifers reared, 97 (37 HF and 60 Jersey), 102 (37 HF and 65 Jersey), 111 (43 HF and 68 Jersey), 107 (42 HF and 65 Jersey), 106 (40 HF and 66 Jersey) and 106 (37 HF and 69 Jersey) heifers from H1,H2; H1,L2; M1,H2; M1,L2; $\mathrm{L} 1, \mathrm{H} 2$; and L1,L2, respectively, were returned to their farm of origin at $22 \mathrm{mo}$.

\section{Growth Performance}

Metabolizable energy intake during period 1 approximated 44, 36, and $33 \mathrm{MJ} / \mathrm{d}$ for $\mathrm{HF}$ on $\mathrm{H} 1, \mathrm{M} 1$, and L1 and approximated 40,32 , and $28 \mathrm{MJ} / \mathrm{d}$ for Jersey on H1, M1, and L1, respectively. Holstein-Friesian heifers consumed approximately 94 and $54 \mathrm{MJ} / \mathrm{d}$ (H2 and L2, respectively); Jersey heifers consumed 85 and $52 \mathrm{MJ} /$ d (H2 and L2, respectively) during period 2. Actual growth rates during periods 1 and 2 were marginally different from those proposed. Holstein-Friesian and Jersey heifers on $\mathrm{H} 1, \mathrm{M} 1$, and $\mathrm{L} 1$ averaged $0.77 \pm 0.097$, $0.53 \pm 0.122$, and $0.37 \pm 0.076 \mathrm{~kg} / \mathrm{d}$ and $0.61 \pm 0.103$, $0.48 \pm 0.070$, and $0.30 \pm 0.053 \mathrm{~kg} / \mathrm{d}$, respectively, during period 1. Growth rates for $\mathrm{H} 2$ and L2 HF and Jersey heifers in period 2 averaged $0.69 \pm 0.122$ and $0.49 \pm$ $0.075 \mathrm{~kg} / \mathrm{d}$ and $0.58 \pm 0.090$ and $0.43 \pm 0.055 \mathrm{~kg} / \mathrm{d}$, respectively, and there were no period interactions.

Six-month heifer BW, wither height, HGC, and BCS at the end of period 1 increased linearly with increased feed allocation (Table 1). As planned, there were no differences between treatments in heifer BW at the end of period 1, although there was a small but significant decline in wither height and HGC as growth rate increased. This result is consistent with results reported by Hoffman et al. (1996) and Van Amburgh et al. (1998). Length of period 1 decreased $(P<0.001)$ linearly with increasing feed allowance and lasted for 135, 200, and $267 \mathrm{~d}$ and 140, 176, and $267 \mathrm{~d}$, respectively for $\mathrm{HF}$ and Jersey groups respectively on H1, M1 and L1.

In accordance with the literature (Lacasse et al., 1993; Peri et al., 1993; Bortone et al., 1994; Van Amburgh et al., 1998), BW at 15 and 22 mo increased linearly $(P<0.001)$ with increasing growth rate during periods 1 and 2, and there was no interaction. At the end of period 2 (22 mo), a 27- and 43-kg BW difference existed between $\mathrm{H} 1$ and M1 and M1 and L1 HF cows, respectively, and a 20 - and 34-kg BW difference existed between $\mathrm{H} 1$ and M1 and M1 and L1 Jersey cows, respectively. The BW difference between HF and Jersey H2 and L2 cows at 22 mo was 70 and $56 \mathrm{~kg}$ of BW, respectively (Table 1). This was a result of an increase $(P<$ 0.001 ) in wither height and HGC (frame size) and also a result of an increase $(P<0.001)$ in stored energy reserves (BCS). Calculated $\mathrm{BW}$ at first calving for $\mathrm{HF}$ heifers on H1,H2; H1,L2; M1,H2; M1,L2; L1,H2; and L1,L2, respectively, were $516,439,485,417,436$ and $378 \mathrm{~kg}$ and were $424,364,403,345,366$, and 313 for Jersey heifers on these same treatments. The H1,H2 heifers attained the recommended calving weight for first lactation grazing heifers (Crosse and Gleeson, 1988; McLean and Freeman, 1996).

The effect of growth rate during periods 1 and 2 on BW, wither height and HGC remained significant at 27 and $39 \mathrm{mo}$, although the differences were substantially less than those recorded at 22 mo (Table 2). The effect of treatment was still evident in BW at 51 mo, but was not significant at the beginning of the fourth lactation (data not shown). Very few studies have measured the long-term effects of heifer growth rates on subsequent heifer size, but Little and Kay (1979) also reported that BW differences between control and accelerated growth rates were evident at the first and second calving. One would also expect this for HGC, considering the strong correlation between BW and HGC reported by Gardner et al. (1977).

\section{Lactational Performance}

Milk production data for lactations 1, 2, and 3 are presented in Table 3, and milk production data corrected for early lactation BW is presented in Table 4 . Milk yields or composition of milk in either breed during the first 2 lactations were not affected by growth rate during period 1 , even though there was a 70 - and 56$\mathrm{kg}$ BW difference between $\mathrm{H} 1$ and L1 HF and Jersey heifers, respectively, at 22 mo of age. When production is corrected for early lactation BW, milk production is reduced as feed allowance during period 1 is increased $(P<0.05$ and 0.001 for HF and Jersey cows, respectively), and the effect is evident in milk component yield 
Table 1. Body weight (kg), BCS, shoulder height (height; $\mathrm{cm}$ ), and heart girth circumference (HGC; $\mathrm{cm}$ ) of Holstein-Friesian (HF) and Jersey heifers at $6 \mathrm{mo}$, the end of period $1^{1}$ (EP1), 15 and 22 mo (end of period $2^{2}$; EP2), and calculated BW at calving. ${ }^{3}$ Heifers were reared at different growth rates $^{4}$ during period 1 (L1, $\mathrm{M} 1$, and H1) and period 2 (L2 and H2).

\begin{tabular}{|c|c|c|c|c|c|c|c|c|c|c|c|c|}
\hline \multirow[b]{2}{*}{ Factor } & \multirow[b]{2}{*}{ Age } & \multirow[b]{2}{*}{ Breed } & \multicolumn{3}{|c|}{ Period 1} & \multicolumn{2}{|c|}{ Period 2} & \multicolumn{2}{|c|}{ SED } & \multicolumn{3}{|c|}{$P$ value } \\
\hline & & & L1 & M1 & H1 & L2 & $\mathrm{H} 2$ & $\mathrm{P} 1$ & P2 & P1 & P2 & $\mathrm{P} 1 \times \mathrm{P} 2$ \\
\hline BW & $6 \mathrm{mo}$ & $\mathrm{HF}$ & 154 & 163 & 174 & - & - & 2.4 & - & $<0.001$ & & \\
\hline Height & $6 \mathrm{mo}$ & $\mathrm{HF}$ & 97 & 99 & 101 & - & - & 0.5 & - & $<0.001$ & & \\
\hline $\mathrm{HGC}$ & $6 \mathrm{mo}$ & $\mathrm{HF}$ & 121 & 124 & 128 & - & - & 0.6 & - & $<0.001$ & & \\
\hline BW & $6 \mathrm{mo}$ & Jersey & 104 & 115 & 125 & - & - & 1.4 & - & $<0.001$ & & \\
\hline Height & $6 \mathrm{mo}$ & Jersey & 90 & 91 & 93 & - & - & 0.4 & - & $<0.001$ & & \\
\hline HGC & $6 \mathrm{mo}$ & Jersey & 109 & 112 & 114 & - & - & 0.6 & - & $<0.001$ & & \\
\hline BW & EP1 & $\mathrm{HF}$ & 201 & 202 & 202 & - & - & 3.1 & - & 0.94 & & \\
\hline BCS & EP1 & $\mathrm{HF}$ & 2.8 & 2.9 & 3.1 & - & - & 0.02 & - & $<0.001$ & & \\
\hline Height & EP1 & $\mathrm{HF}$ & 107 & 107 & 104 & - & - & & - & $<0.001$ & & \\
\hline HGC & EP1 & $\mathrm{HF}$ & 136 & 136 & 133 & - & - & 0.8 & - & $<0.001$ & & \\
\hline BW & EP1 & Jersey & 159 & 164 & 163 & - & - & 2.1 & - & 0.052 & & \\
\hline BCS & EP1 & Jersey & 2.7 & 2.9 & 3.0 & - & - & 0.02 & - & $<0.001$ & & \\
\hline Height & EP1 & Jersey & 103 & 101 & 101 & - & - & 0.3 & - & $<0.001$ & & \\
\hline $\mathrm{HGC}$ & EP1 & Jersey & 129 & 127 & 125 & - & - & 0.6 & - & $<0.001$ & & \\
\hline BW & 15 & $\mathrm{HF}$ & 281 & 323 & 347 & 308 & 326 & 4.3 & 3.6 & $<0.001$ & $<0.001$ & $<0.05$ \\
\hline Height & 15 & $\mathrm{HF}$ & 116 & 119 & 120 & 118 & 119 & 0.5 & 0.4 & $<0.001$ & 0.016 & 0.28 \\
\hline BW & 15 & Jersey & 210 & 240 & 256 & 227 & 243 & 2.7 & 2.2 & $<0.001$ & $<0.01$ & 0.01 \\
\hline Height & 15 & Jersey & 106 & 109 & 110 & & & 0.4 & & $<0.001$ & & \\
\hline BW & EP2 & $\mathrm{HF}$ & 382 & 425 & 452 & 385 & 455 & & & $<0.001$ & $<0.001$ & 0.57 \\
\hline BCS & EP2 & $\mathrm{HF}$ & 3.0 & 3.1 & 3.2 & 2.9 & 3.2 & 0.03 & 0.03 & $<0.001$ & & 0.71 \\
\hline Height & EP2 & $\mathrm{HF}$ & 124 & 126 & 128 & 125 & 127 & 0.5 & 0.4 & $<0.001$ & $<0.001$ & 0.20 \\
\hline HGC & EP2 & $\mathrm{HF}$ & 170 & 177 & 182 & 170 & 182 & 0.9 & 0.7 & $<0.001$ & $<0.001$ & 0.09 \\
\hline BW & EP2 & Jersey & 319 & 353 & 373 & 320 & 376 & 3.5 & 2.8 & $<0.001$ & $<0.001$ & 0.38 \\
\hline BCS & EP2 & & 3.0 & 3.1 & 3.2 & 3.0 & 3.3 & 0.02 & 0.01 & & & $<0.001$ \\
\hline Height & EP2 & Jersey & 116 & 117 & 119 & 116 & 118 & 0.3 & 0.3 & $<0.001$ & $<0.001$ & 0.81 \\
\hline HGC & EP2 & Jersey & 159 & 165 & 168 & 160 & 169 & 0.7 & 0.5 & $<0.001$ & $<0.001$ & 0.24 \\
\hline BW & Calving & $\mathrm{HF}$ & 408 & 451 & 476 & 411 & 479 & 6.1 & 5.0 & $<0.001$ & $<0.001$ & 0.30 \\
\hline BW & Calving & Jersey & 339 & 374 & 394 & 340 & 398 & 3.7 & 3.0 & $<0.001$ & $<0.001$ & 0.59 \\
\hline
\end{tabular}

\footnotetext{
${ }^{1}$ Period 1 consisted of the period between 100 and $200 \mathrm{~kg}$ of BW (HF) or 80 and $165 \mathrm{~kg}$ of BW (Jersey)

${ }^{2}$ Period 2 consisted of the period between $200 \mathrm{~kg}$ of BW (HF) or $165 \mathrm{~kg}$ of BW (Jersey) and $22 \mathrm{mo}$.

${ }^{3}$ Body weight at calving was calculated from BW at 22 mo and using the regression equations developed by Prior and Laster (1979), assuming calf birth weight = maternal birth weight.

${ }^{4}$ Holstein-Friesian and Jersey calves, respectively, were fed to achieve average daily growth rates of 0.80 and $0.65 \mathrm{~kg}$ of BW/d [high growth rate during period 1 (H1)], 0.60 and $0.50 \mathrm{~kg}$ of BW/d [medium growth rate during period 1 (M1)] or 0.40 and $0.35 \mathrm{~kg}$ of BW/d [low rate of growth during period 1 (L1)] and 0.70 and $0.60 \mathrm{~kg}$ of BW/d [high growth rate during period $2(\mathrm{H} 2)$ ] or 0.50 and $0.40 \mathrm{~kg}$ of BW/d [low growth rate during period 2 (L2)].
}

for 2 lactations in HF cows and for 3 lactations in Jersey cows.

Heifers on the low plane of nutrition in period 2 produced 7\% less milk $(P<0.01 ; \mathrm{HF}, 7 \%$; Jersey $6 \%)$, $8 \%$ less milk fat $(P<0.01 ; \mathrm{HF}, 9 \%$; Jersey, $6 \%)$, and $6 \%$ less protein $(P<0.001 ; \mathrm{HF}, 6 \%$; Jersey, $5 \%)$ compared with heifers in the $\mathrm{H} 2$ treatment group during their first lactation, showing obvious benefits in first-lactation milk production from increased animal size. No difference in any aspect of milk production was detected in subsequent lactations.

Although significant research has been undertaken, the effect of average daily BW gain pre- and postpuberty and the effect of heifer BW at calving on milk production remains uncertain. This is particularly evident in pas- ture-based systems where cows cannot achieve the DMI reported in stall-feeding systems (Kolver and Muller, 1998). Many studies have reported milk production benefits from increased first-calving BW in grazing heifers (Cowen et al., 1974; Kerr et al., 1985; Crosse and Gleeson, 1988; Freeman, 1995), but studies have also shown no effect of animal size at first calving (Thomas and Mickan, 1987; Stewart and Taylor, 1990; Carson et al., 2000). In the study presented here, BW differences as a result of prepubertal nutrition did not affect milk production, but BW differences as a result of postpubertal nutrition did. This suggests that the effect of heifer size on subsequent milk production is not as simple as merely first-calving BW, but also involves the management decisions by which that final BW was arrived. 
Table 2. Body weight (kg), BCS, shoulder height (height; $\mathrm{cm}$ ), and heart girth circumference (HGC; $\mathrm{cm}$ ) of Holstein-Friesian (HF) and Jersey heifers reared at different growth rates ${ }^{1}$ during period $1^{2}$ (L1, M1, and H1) and period $2^{3}$ (L2 and H2).

\begin{tabular}{|c|c|c|c|c|c|c|c|c|c|c|c|c|}
\hline \multirow[b]{2}{*}{ Factor } & \multirow[b]{2}{*}{ Age } & \multirow[b]{2}{*}{ Breed } & \multicolumn{3}{|c|}{ Period 1} & \multicolumn{2}{|c|}{ Period 2} & \multicolumn{2}{|c|}{ SED } & \multicolumn{3}{|c|}{$P$ value } \\
\hline & & & L1 & M1 & H1 & L1 & H1 & $\mathrm{P} 1$ & P2 & $\mathrm{P} 1$ & $\mathrm{P} 2$ & $\mathrm{P} 1 \times \mathrm{P} 2$ \\
\hline BW & 27 & $\mathrm{HF}$ & 379 & 397 & 408 & 386 & 403 & 5.3 & 4.3 & $<0.001$ & $<0.001$ & 0.87 \\
\hline BCS & 27 & $\mathrm{HF}$ & 3.0 & 3.0 & 3.0 & 3.0 & 3.0 & 0.02 & 0.02 & 0.20 & 0.25 & 0.80 \\
\hline Height & 27 & $\mathrm{HF}$ & 125 & 128 & 128 & 126 & 128 & 0.6 & 0.5 & $<0.001$ & $<0.01$ & 0.61 \\
\hline HGC & 27 & $\mathrm{HF}$ & 170 & 173 & 176 & 172 & 175 & 0.8 & 0.6 & $<0.001$ & $<0.001$ & 0.50 \\
\hline BW & 27 & Jersey & 291 & 304 & 313 & 295 & 310 & 3.3 & 2.7 & $<0.001$ & $<0.001$ & 0.69 \\
\hline BCS & 27 & Jersey & 2.9 & 2.9 & 2.9 & 2.9 & 2.9 & 0.02 & 0.01 & 0.85 & 0.06 & 0.72 \\
\hline Height & 27 & Jersey & 116 & 118 & 119 & 117 & 119 & 0.4 & 0.3 & $<0.001$ & $<0.001$ & 0.88 \\
\hline HGC & 27 & Jersey & 158 & 160 & 162 & 158 & 162 & 0.6 & 0.5 & $<0.001$ & $<0.001$ & 0.72 \\
\hline BW & 39 & $\mathrm{HF}$ & 405 & 419 & 424 & 412 & 420 & 6.0 & 4.9 & $<0.01$ & 0.12 & 0.74 \\
\hline BCS & 39 & $\mathrm{HF}$ & 2.9 & 2.9 & 2.8 & 2.9 & 2.8 & 0.03 & 0.02 & 0.10 & 0.14 & 0.75 \\
\hline Height & 39 & $\mathrm{HF}$ & 127 & 130 & 130 & 129 & 129 & 0.6 & 0.5 & $<0.001$ & 0.39 & 0.46 \\
\hline HGC & 39 & $\mathrm{HF}$ & 176 & 178 & 180 & 177 & 179 & 0.9 & 0.7 & $<0.001$ & $<0.05$ & 0.40 \\
\hline BW & 39 & Jersey & 321 & 331 & 343 & 328 & 335 & 3.5 & 2.8 & $<0.001$ & $<0.01$ & 0.88 \\
\hline $\mathrm{BCS}$ & 39 & Jersey & 2.8 & 2.8 & 2.8 & 2.8 & 2.8 & 0.02 & 0.01 & 0.53 & 0.49 & 0.07 \\
\hline Height & 39 & Jersey & 119 & 120 & 121 & 120 & 121 & 0.4 & 0.3 & $<0.001$ & $<0.05$ & 0.56 \\
\hline HGC & 39 & Jersey & 159 & 161 & 162 & 160 & 162 & 0.6 & 0.5 & $<0.001$ & $<0.01$ & 0.51 \\
\hline BW & 51 & $\mathrm{HF}$ & 439 & 450 & 461 & 448 & 452 & 6.9 & 5.7 & $<0.01$ & 0.58 & 0.76 \\
\hline BCS & 51 & $\mathrm{HF}$ & 2.9 & 2.8 & 2.8 & 2.9 & 2.8 & 0.04 & 0.03 & 0.19 & 0.12 & 0.71 \\
\hline BW & 51 & Jersey & 345 & 358 & 363 & 352 & 359 & 4.2 & 3.4 & $<0.001$ & $<0.05$ & 0.42 \\
\hline BCS & 51 & Jersey & 2.8 & 2.8 & 2.9 & 2.8 & 2.9 & 0.02 & 0.02 & 0.64 & 0.10 & 0.93 \\
\hline
\end{tabular}

${ }^{1}$ Holstein-Friesian and Jersey calves, respectively, were fed to achieve average daily growth rates of 0.80 and $0.65 \mathrm{~kg}$ of BW/d [high growth rate during period 1 (H1)], 0.60 and $0.50 \mathrm{~kg}$ of BW/d [medium growth rate during period 1 (M1)] or 0.40 and $0.35 \mathrm{~kg}$ of BW/d [low rate of growth during period 1 (L1)] and 0.70 and $0.60 \mathrm{~kg}$ of BW/d [high growth rate during period $2(\mathrm{H} 2)$ ] or 0.50 and $0.40 \mathrm{~kg}$ of BW/d [low growth rate during period 2 (L2)].

${ }^{2}$ Period 1 consisted of the period between 100 and $200 \mathrm{~kg}$ of BW (HF) or 80 and $165 \mathrm{~kg}$ of BW (Jersey).

${ }^{3}$ Period 2 consisted of the period between $200 \mathrm{~kg}$ of BW (HF) or $165 \mathrm{~kg}$ of BW (Jersey) and $22 \mathrm{mo.}$

This is consistent with the findings of Crichton et al. (1960), who found that a low feeding level during pregnancy only reduced first-lactation milk production when combined with an elevated plane of nutrition prepuberty. Regardless, benefits from increased heifer size at first calving in seasonal pasture-based systems were only evident in lactation 1.

Extensive investigations have been undertaken relative to nutrition during the pre- and postpubertal stages of heifer rearing, but effects on mammary development and consequent milk production have been inconsistent. Little and Kay (1979) reported a negative effect of rapid prepubertal rearing on subsequent milk production, regardless of the age at first calving. These results were supported by Foldager and Sejrsen (1987) and Ingvartsen et al. (1988), who demonstrated significant reductions in milk yield when prepubertal growth rates exceeded 0.6 and $0.42 \mathrm{~kg} / \mathrm{d}$ in $\mathrm{HF}$ and Jersey heifers, respectively. Recent results (Lammers et al., 1999; Radcliff et al., 2000) also suggested a 7 to $14 \%$ reduction in first lactation milk yields as a result of excessive prepubertal heifer growth. In comparison, in the current study, high prepubertal growth rates did not appear to affect milk production until lactation 3 .
However, if greater BW at calving increases milk production, as data from period 2 suggest, adjusting for the positive effect of high feed allowance in period 1 on cow BW at calving may provide a better indication of the effect of prepubertal nutrition on milk production. Table 4 shows the BW-adjusted milk production from periods 1 and 2 . These data imply that a high feed allowance prepuberty to achieve growth rates of 0.77 or $0.61 \mathrm{~kg} / \mathrm{d}$ in $\mathrm{HF}$ and Jersey cows, respectively, reduces the yield of milk and milk components during the first 2 lactations in HF cows and during the first 3 lactations recorded in Jersey cows.

However, care must be taken in interpreting these data because adjustment for BW alone also suggests that elevated growth rate in period 2 reduced $(P<0.01)$ the yield of milk, fat, and protein in Jersey cows. Although there is limited evidence (Hoffman et al., 1996) of a negative effect of very high $(>0.8 \mathrm{~kg} / \mathrm{d}$ ) postpubertal growth rates on first-lactation milk production, heifers on the current study did not attain such high growth rates, and the negative effect suggested in Jersey cows when milk production data are adjusted for BW is unlikely to be true. Nevertheless, the BW-corrected data do suggest a long-term negative effect of accelerated 
Table 3. Mean annual milk yield (kg), milk component yield (kg), and milk composition (\%) for the first 3 lactations (Lact) of HolsteinFriesian (HF) and Jersey heifers offered different pasture allowances to achieve different growth rates ${ }^{1}$ during period $1^{2}$ (L1, M1, and H1) and period $2^{3}$ (L2 and H2).

\begin{tabular}{|c|c|c|c|c|c|c|c|c|c|c|c|c|}
\hline Factor & Breed & Lact & \multicolumn{3}{|c|}{ Period 1} & \multicolumn{2}{|c|}{ Period 2} & \multicolumn{2}{|c|}{ SED } & \multicolumn{3}{|c|}{$P$ value } \\
\hline \multicolumn{13}{|l|}{ Milk yield } \\
\hline Milk & $\mathrm{HF}$ & 2 & 3817 & 3774 & 3723 & 3775 & 3768 & 103.1 & 84.3 & 0.68 & 0.88 & 0.52 \\
\hline Milk & $\mathrm{HF}$ & 3 & 4169 & 3804 & 4015 & 4089 & 3903 & 149.5 & 121.3 & 0.06 & 0.12 & 0.66 \\
\hline Milk & Jersey & 1 & 2535 & 2629 & 2579 & 2504 & 2658 & 58.4 & 47.7 & 0.26 & $<0.01$ & 0.10 \\
\hline Fat & $\mathrm{HF}$ & 1 & 146 & 151 & 148 & 143 & 154 & 4.0 & 3.2 & 0.45 & $<0.001$ & 0.75 \\
\hline Fat & $\mathrm{HF}$ & 2 & 175 & 174 & 168 & 172 & 173 & 4.7 & 3.9 & 0.32 & 0.83 & 0.35 \\
\hline Fat & $\mathrm{HF}$ & 3 & 188 & 172 & 179 & 184 & 176 & 6.7 & 5.4 & 0.07 & 0.16 & 0.25 \\
\hline Fat & Jersey & 1 & 145 & 151 & 149 & 145 & 152 & 3.3 & 2.7 & 0.12 & 0.01 & 0.19 \\
\hline Fat & Jersey & 2 & 154 & 156 & 151 & 154 & 154 & 3.6 & 2.9 & 0.35 & 0.83 & 0.77 \\
\hline Fat & Jersey & 3 & 156 & 165 & 153 & 159 & 157 & 3.7 & 3.0 & $<0.01$ & 0.63 & 0.75 \\
\hline Protein & Jersey & 3 & 110 & 115 & 108 & 110 & 112 & 2.4 & 2.0 & $<0.01$ & 0.47 & 0.12 \\
\hline \multicolumn{13}{|c|}{ Milk composition } \\
\hline Fat & $\mathrm{HF}$ & 1 & 4.52 & 4.60 & 4.55 & 4.54 & 4.58 & 0.078 & 0.064 & 0.62 & 0.56 & 0.78 \\
\hline Fat & $\mathrm{HF}$ & 2 & 4.58 & 4.63 & 4.54 & 4.57 & 4.60 & 0.086 & 0.070 & 0.52 & 0.61 & $<0.01$ \\
\hline Fat & $\mathrm{HF}$ & 3 & 4.53 & 4.55 & 4.48 & 4.52 & 4.53 & 0.108 & 0.087 & 0.81 & 0.79 & 0.03 \\
\hline Fat & Jersey & 1 & 5.75 & 5.77 & 5.78 & 5.82 & 5.72 & 0.064 & 0.052 & 0.88 & 0.07 & 0.89 \\
\hline Fat & Jersey & 2 & 5.75 & 5.80 & 5.78 & 5.82 & 5.73 & 0.071 & 0.058 & 0.81 & 0.13 & 0.97 \\
\hline Fat & Jersey & 3 & 5.75 & 5.82 & 5.85 & 5.84 & 5.77 & 0.085 & 0.069 & 0.45 & 0.44 & $<0.05$ \\
\hline Protein & $\mathrm{HF}$ & 1 & 3.46 & 3.53 & 3.47 & 3.50 & 3.47 & 0.043 & 0.035 & 0.23 & 0.53 & 0.61 \\
\hline Protein & $\mathrm{HF}$ & 2 & 3.48 & 3.50 & 3.47 & 3.46 & 3.50 & 0.048 & 0.039 & 0.82 & 0.21 & 0.89 \\
\hline Protein & $\mathrm{HF}$ & 3 & 3.47 & 3.51 & 3.49 & 3.48 & 3.50 & 0.051 & 0.041 & 0.76 & 0.53 & 0.62 \\
\hline Protein & Jersey & 1 & 3.98 & 3.94 & 3.96 & 3.99 & 3.94 & 0.030 & 0.025 & 0.44 & 0.07 & 0.75 \\
\hline
\end{tabular}

${ }^{1}$ Holstein-Friesian and Jersey calves, respectively, were fed to achieve average daily growth rates of 0.80 and $0.65 \mathrm{~kg}$ of BW/d [high growth rate during period $1(\mathrm{H} 1)$ ], 0.60 and $0.50 \mathrm{~kg}$ of BW/d [medium growth rate during period 1 (M1)] or 0.40 and $0.35 \mathrm{~kg}$ of BW/d [low rate of growth during period 1 (L1)] and 0.70 and $0.60 \mathrm{~kg}$ of BW/d [high growth rate during period 2 (H2)] or 0.50 and $0.40 \mathrm{~kg}$ of BW/d [low growth rate during period 2 (L2)].

${ }^{2}$ Period 1 consisted of the period between 100 and $200 \mathrm{~kg}$ of BW (HF) or 80 and $165 \mathrm{~kg}$ of BW (Jersey).

${ }^{3}$ Period 2 consisted of the period between $200 \mathrm{~kg}$ of BW (HF) or $165 \mathrm{~kg}$ of BW (Jersey) $22 \mathrm{mo}$.

prepubertal growth rate, potentially suggesting reduced mammary development in grazing heifers fed to achieve accelerated growth rates.

The accelerated prepubertal growth rate-derived reduction in milk yield was originally postulated to be a result of reduced mammary parenchymal development and increased mammary fat pad development (Harrison et al., 1983; Capuco et al., 1995), possibly mediated through effects of reduced growth hormone secretion (Sejrsen et al., 1986). The mammary gland undergoes 3 distinct growth phases (allometric before puberty and following breeding and isometric during the peripubescent period), and it has generally been believed that nutrition during the phases of allometric growth can affect mammary development (Valentine et al.,
1987). Recent results by Meyer et al. (2004) suggest no effect of nutrition on daily parenchymal development in heifers reared at either 0.65 or $0.95 \mathrm{~kg} / \mathrm{d}$ to puberty. However, the onset of puberty was advanced in the heifers experiencing accelerated growth resulting in less total parenchymal development during the first phase of allometric growth, and a reduction in potential milk production.

These results (Meyer et al., 2004) are consistent with those of Capuco et al. (1995). However, although Capuco et al. (1995) found a similar reduction in total parenchymal development during the first allometric phase in heifers raised at $0.95 \mathrm{vs} .0 .73 \mathrm{~kg} / \mathrm{d}$, they did not find an effect of prepubertal nutrition on first-lactation milk production. Such results are consistent with the lack of 
Table 4. Mean annual milk and component yield (kg) for the first 3 lactations (Lact) of Holstein-Friesian (HF) and Jersey heifers adjusted for BW at the beginning of the respective lactations. Heifers were offered different pasture allowances to achieve different growth rates $^{1}$ during period $1^{2}(\mathrm{~L} 1, \mathrm{M} 1$, and H1) and period $2^{3}$ (L2 and H2).

\begin{tabular}{|c|c|c|c|c|c|c|c|c|c|c|c|c|}
\hline \multirow[b]{2}{*}{ Factor } & \multirow[b]{2}{*}{ Breed } & \multirow[b]{2}{*}{ Lact } & \multicolumn{3}{|c|}{ Period 1} & \multicolumn{2}{|c|}{ Period 2} & \multicolumn{2}{|c|}{ SED } & \multicolumn{2}{|c|}{$P$ value } & \multirow[b]{2}{*}{$\mathrm{P} 1 \times \mathrm{P} 2$} \\
\hline & & & L1 & M1 & $\mathrm{H} 1$ & L2 & $\mathrm{H} 2$ & $\mathrm{P} 1$ & $\mathrm{P} 2$ & $\mathrm{P} 1$ & $\mathrm{P} 2$ & \\
\hline \multicolumn{13}{|c|}{ Milk yield } \\
\hline Milk & $\mathrm{HF}$ & 1 & 3423 & 3290 & 3133 & 3340 & 3224 & 91.9 & 91.2 & $<0.05$ & 0.21 & 0.92 \\
\hline Milk & $\mathrm{HF}$ & 2 & 3863 & 3766 & 3664 & 3803 & 3726 & 105.4 & 85.7 & 0.19 & 0.34 & 0.45 \\
\hline Milk & $\mathrm{HF}$ & 3 & 4073 & 3867 & 4034 & 4034 & 3949 & 124.5 & 101.4 & 0.24 & 0.37 & 0.44 \\
\hline Milk & Jersey & 1 & 2725 & 2598 & 2426 & 2677 & 2489 & 63.0 & 63.2 & $<0.001$ & $<0.01$ & $<0.001$ \\
\hline Milk & Jersey & 2 & 2730 & 2716 & 2581 & 2671 & 2681 & 58.9 & 47.0 & $<0.05$ & 0.85 & 0.17 \\
\hline Milk & Jersey & 3 & 2749 & 2826 & 2630 & 2747 & 2722 & 60.5 & 48.9 & $<0.01$ & 0.535 & 0.018 \\
\hline Fat & $\mathrm{HF}$ & 1 & 154 & 150 & 142 & 150 & 147 & 4.2 & 4.2 & $<0.05$ & 0.46 & 0.18 \\
\hline Fat & $\mathrm{HF}$ & 2 & 177 & 174 & 165 & 172 & 172 & 4.8 & 3.9 & 0.07 & 0.90 & 0.09 \\
\hline Fat & $\mathrm{HF}$ & 3 & 186 & 177 & 180 & 182 & 179 & 5.7 & 4.7 & 0.23 & 0.55 & 0.39 \\
\hline Fat & Jersey & 1 & 158 & 149 & 138 & 157 & 140 & 3.4 & 3.5 & $<0.001$ & $<0.001$ & $<0.001$ \\
\hline Fat & Jersey & 2 & 158 & 157 & 149 & 156 & 153 & 3.5 & 2.8 & $<0.05$ & 0.35 & 0.09 \\
\hline Fat & Jersey & 3 & 160 & 163 & 152 & 160 & 157 & 3.7 & 3.0 & $<0.01$ & 0.28 & 0.07 \\
\hline Protein & $\mathrm{HF}$ & 1 & 117 & 115 & 109 & 116 & 112 & 3.0 & 3.0 & $<0.05$ & 0.28 & 0.18 \\
\hline Protein & $\mathrm{HF}$ & 2 & 135 & 131 & 126 & 131 & 131 & 3.6 & 2.9 & 0.09 & 0.93 & 0.36 \\
\hline Protein & $\mathrm{HF}$ & 3 & 142 & 136 & 140 & 141 & 138 & 3.7 & 3.0 & 0.24 & 0.29 & 0.55 \\
\hline Protein & Jersey & 1 & 110 & 102 & 95 & 108 & 97 & 2.5 & 2.5 & $<0.001$ & $<0.001$ & $<0.001$ \\
\hline Protein & Jersey & 2 & 111 & 110 & 104 & 108 & 109 & 2.4 & 1.9 & 0.012 & 0.69 & 0.09 \\
\hline Protein & Jersey & 3 & 112 & 115 & 107 & 111 & 112 & 2.4 & 2.0 & $<0.01$ & 0.96 & $<0.05$ \\
\hline
\end{tabular}

${ }^{1}$ Holstein-Friesian and Jersey calves, respectively, were fed to achieve average daily growth rates of 0.80 and $0.65 \mathrm{~kg}$ of BW/d [high growth rate during period 1 (H1)], 0.60 and $0.50 \mathrm{~kg}$ of BW/d [medium growth rate during period 1 (M1)] or 0.40 and $0.35 \mathrm{~kg}$ of BW/d [low rate of growth during period 1 (L1)] and 0.70 and $0.60 \mathrm{~kg}$ of BW/d [high growth rate during period $2(\mathrm{H} 2)$ ] or 0.50 and $0.40 \mathrm{~kg}$ of BW/d [low growth rate during period 2 (L2)].

${ }^{2}$ Period 1 consisted of the period between 100 and $200 \mathrm{~kg}$ of BW (HF) or 80 and $165 \mathrm{~kg}$ of BW (Jersey).

${ }^{3}$ Period 2 consisted of the period between $200 \mathrm{~kg}$ of BW (HF) or $165 \mathrm{~kg}$ of BW (Jersey) and $22 \mathrm{mo.}$

effect of prepubertal nutrition on actual first-lactation milk production in the current study and with the reports of others (Gaynor et al., 1995; Abeni et al., 2000). However, as outlined earlier, the effect may be masked by BW at calving, particularly in the current study. Other studies have shown reduced milk production with accelerated prepubertal growth (Lammers et al., 1999; Radcliff et al., 2000). The inconsistency in previously reported results may be a result of confounding effects of postpubertal management (Van Amburgh et al., 1998), age at first calving (Abeni et al., 2000), feed type used to achieve the required accelerated growth (Silva et al., 2002), a combination of these factors or the duration of the experiment.

Earlier breeding (as a result of earlier puberty in heifers experiencing elevated growth) will reduce the total time available for mammary development (shorter first allometric growth phase), and this may be a factor in reduced production rather than accelerated BW gain (Abeni et al., 2000). All heifers in the current study were mated at the same age, removing this potential confounder. However, the results of Little and Kay (1979), where elevated prepubertal growth rates reduced first-lactation milk production, regardless of age at first calving, suggest that earlier breeding is not the sole cause of the decline.

Van Amburgh et al. (1998) reported a reduction in FCM yield in heifers grown at 0.94 vs. $0.68 \mathrm{~kg} / \mathrm{d}$, but found that prepubertal rate of gain only explained $8 \%$ of variation. Instead, those researchers found a significant effect of postpubertal factors. They reported a negative relationship between prepubertal BW gain and postpubertal BW gain (postpubertal compensatory growth) and concluded that this nullified any impact of prepubertal nutrition. This is consistent with the earlier results reported by Crichton et al. (1960) and the results of the current study, where heifers experiencing higher prepubertal growth rates had lower BW-corrected milk yields, but actual milk yields were not different.

Silva et al. (2002) reported that the effect of prepubertal nutrition may not be growth rate per se, but may be related to the type of growth. Their results suggest that increased body fatness at breeding may be a better predictor of impaired mammary development than growth rate. The study reported here does not allow us to examine that effect of different diet types; however, the $\mathrm{H} 1$ heifers were fatter at mating and had lower BW- 
corrected milk production, which support the findings of Silva et al. (2002).

The effect of body fatness at breeding is an important factor to consider, particularly in pasture-based systems where heifers are generally fed all-forage diets with little concentrate feed inputs. Such a diet would not be expected to result in as great a degree of lipogenesis as a diet containing large amounts of concentrate feeds. Another feature of pasture systems is the increased exercise undertaken by heifers to achieve their daily DMI. This would also probably result in a proportionally leaner heifer than one reared in confinement.

Another possible reason for the inconsistent results is the duration of the heifer rearing experiments. Many of the heifer rearing experiments were short term ( 1 or 2 lactations) and might not have been long enough to witness the negative effect of prepubertal rearing. High prepubertal growth rates resulted in larger heifers at calving in seasonal systems (Table 1). Larger heifers as a result of postpubertal level of feeding (H2) produced more milk than their smaller counterparts (L2). However, no such effect was evident in larger heifers as a result of prepubertal feeding (H1). It is possible that the larger frame size and resultant greater potential DMI compensated for any reduced mammary development in the $\mathrm{H} 1$ heifers, masking the negative effect of prepubertal growth rates on milk production. The reduced BW-adjusted milk production during the first 2 lactations and the lower actual milk production in these cows during the third lactation, when BW differences were much smaller, supports this hypothesis. Also consistent with this are the results of Lammers et al. (1999) and Radcliff et al. (2000), where heifers were bred at a specific weight, resulting in similar calving BW across treatments, and lower first lactation milk productions were recorded. This is an important point of consideration for future research in this area.

It could be argued that a prepubertal growth rate of $0.77 \mathrm{~kg} / \mathrm{d}$ in $\mathrm{HF}$ and $0.61 \mathrm{~kg} / \mathrm{d}$ in Jersey were too low to illicit a reduction in milk production. For example, Lammers et al. (1999) compared 0.7 and $1.0 \mathrm{~kg} / \mathrm{d}$. However, accelerated prepubertal growth should probably be defined relative to final heifer calving weight. For example, negative effects of accelerated prepubertal growth rate are reported at lower daily BW gain in Jersey than in HF (0.42 vs. $0.6 \mathrm{~kg} / \mathrm{d}$; Foldager and Sejrsen, 1987; Ingvartsen et al., 1988). Similarly, the HF heifers used in the current experiment would be expected to be genetically smaller than the HF heifers of North American genotype used in previous research (Kolver et al., 2002), and the growth rates achieved must be viewed in this context. For example, heifer calving BW in the current experiment was 33\% less than reported by Lammers et al. (1999), which suggests that the accelerated prepubertal growth rates achieved in the current experiment $(0.77 \mathrm{~kg} / \mathrm{d})$ were equivalent to the $1.0 \mathrm{~kg} / \mathrm{d}$ achieved by Lammers et al. (1999).

The suggested negative effect of prepubertal growth rates and positive effect, albeit short term, of postpubertal growth rates on milk production suggest that it is important to focus on the postpubertal rearing period for accelerated growth, even in pasture-based systems. This result is consistent with the reported positive milk production effects of stair-step growth patterns (Choi et al., 1997; Park et al., 1998; Ford and Park, 2001), where heifers undergo periods of restriction followed by periods of accelerated compensatory growth. Park et al. (1989) observed that the intensity of mammary development induced by a stair-step compensatory growth pattern was greater than that of heifers fed conventionally. The increased first lactation milk production in heifers on the high postpubertal plane of nutrition (second allometric growth phase) in the current study supports this.

\section{Reproductive Performance}

Consistent with earlier reports (Foldager et al., 1988; Niezen et al., 1996; Peri et al., 1993), the onset of puberty occurred at the same BW in all treatments (251 \pm 25.4 and $180 \pm 24.0 \mathrm{~kg}$ of BW for HF and Jersey, respectively). Consequently, as reported by Foldager et al. (1988), age at puberty was inversely related to rate of BW gain during period $1(P<0.001 ; 355,383$, and $419 \mathrm{~d}$ for $\mathrm{HF}$ heifers on $\mathrm{H} 1, \mathrm{M} 1$, and $\mathrm{L} 1$ respectively; $P<0.001 ; 291,344$, and 398 d for Jersey heifers on H1, $\mathrm{M} 1$, and L1 respectively, and during period $2(P<0.05$; 380 and $390 \mathrm{~d}$ for HF heifers on $\mathrm{H} 2$ and L2 respectively; $P<0.001 ; 335$ and $352 \mathrm{~d}$ for Jersey heifers on $\mathrm{H} 2$ and L2, respectively.

As a result of delayed onset of puberty in heifers subjected to a lower feed allowance, prepubertal growth rate was positively associated with the proportion of heifers cycling at PSM $(100,98$, and $81 \%$ of HF and 98 , 96 , and $68 \%$ of Jersey were cycling at PSM for H1, M1, and L1 treatment groups, respectively). Estrus was synchronized at $15 \mathrm{mo}$, and despite large differences in $\mathrm{BW}$, days to conception post-synchronization was not affected by treatment or breed (13 \pm 2.4$)$. Similarly, conception rate during the 10 -wk breeding period was not affected by treatment in either period $(91,95,93$, 96, 93, and $88 \%$ for $\mathrm{HF}$ and $85,96,97,94,93$, and $93 \%$ for Jersey on HH, HL, MH, ML, LH, and LL, respectively).

Based on these results, in a seasonal system where heifers are required to calve at $24 \mathrm{mo}$, heifer daily BW gain is unlikely to affect reproductive management, although intervention is more likely to be required to 
Table 5. Proportion of Holstein-Friesian (HF) and Jersey heifers offered different pasture allowances to achieve different growth rates ${ }^{1}$ during period $1^{2}$ (L1, M1, and H1) and period $2^{3}$ (L2 and H2) that survived to $22 \mathrm{mo}$ and the proportion of first-calved heifers that survived to their second and third lactation.

\begin{tabular}{|c|c|c|c|c|c|c|c|c|c|c|c|}
\hline \multirow[b]{2}{*}{ Breed } & \multirow[b]{2}{*}{ Lact } & \multicolumn{3}{|c|}{ Period 1} & \multicolumn{2}{|c|}{ Period 2} & \multicolumn{2}{|c|}{ SED } & \multicolumn{3}{|c|}{$P$ value } \\
\hline & & L1 & M1 & H1 & L2 & $\mathrm{H} 2$ & P1 & $\mathrm{P} 2$ & P1 & $\mathrm{P} 2$ & $\mathrm{P} 1 \times \mathrm{P} 2$ \\
\hline $\mathrm{HF}$ & 1 & 0.94 & 0.94 & 0.88 & 0.92 & 0.92 & 0.036 & 0.033 & 0.22 & 0.86 & 0.77 \\
\hline Jersey & 1 & 0.95 & 0.92 & 0.88 & 0.93 & 0.91 & 0.035 & 0.026 & 0.08 & 0.40 & 0.04 \\
\hline $\mathrm{HF}$ & 2 & 0.87 & 0.88 & 0.89 & 0.89 & 0.86 & 0.054 & 0.042 & 0.93 & 0.47 & 0.39 \\
\hline $\mathrm{HF}$ & 3 & 0.71 & 0.68 & 0.70 & 0.70 & 0.68 & 0.076 & 0.061 & 0.94 & 0.75 & 0.52 \\
\hline Jersey & 2 & 0.87 & 0.88 & 0.87 & 0.85 & 0.90 & 0.043 & 0.034 & 0.94 & 0.19 & 0.85 \\
\hline Jersey & 3 & 0.78 & 0.78 & 0.68 & 0.72 & 0.77 & 0.054 & 0.043 & 0.12 & 0.29 & 0.22 \\
\hline
\end{tabular}

${ }^{1}$ Holstein-Friesian and Jersey calves, respectively, were fed to achieve average daily growth rates of 0.80 and $0.65 \mathrm{~kg}$ of BW/d [high growth rate during period 1 (H1)], 0.60 and $0.50 \mathrm{~kg}$ of BW/d [medium growth rate during period 1 (M1)] or 0.40 and $0.35 \mathrm{~kg}$ of BW/d [low rate of growth during period 1 (L1)] and 0.70 and $0.60 \mathrm{~kg}$ of BW/d [high growth rate during period $2(\mathrm{H} 2)$ ] or 0.50 and $0.40 \mathrm{~kg}$ of BW/d [low growth rate during period 2 (L2)].

${ }^{2}$ Period 1 consisted of the period between 100 and $200 \mathrm{~kg}$ of BW (HF) or 80 and $165 \mathrm{~kg}$ of BW (Jersey).

${ }^{3}$ Period 2 consisted of the period between $200 \mathrm{~kg}$ of BW (HF) or $165 \mathrm{~kg}$ of BW (Jersey) and $22 \mathrm{mo}$.

stimulate the onset of puberty and estrus in heifers reared on a low plane of nutrition. One of the reasons for interest in the area of heifer growth rates is to enable earlier breeding and to shorten the nonproductive phase of the dairy cow's life (Capuco et al., 1995; Sejrsen and Purup, 1997). In such nonseasonal dairying systems, lower prepubertal daily BW gain will delay first calving. It is not possible to say to what extent from the current dataset because estrus was synchronized, but Van Amburgh et al. (1998) investigated the effect of prepubertal growth rate and reported a delayed onset of estrus of $2 \mathrm{~d}$ in all low BW gain heifers and $12 \mathrm{~d}$ in low BW gain heifers that conceived.

There was no effect of treatment on first calving date (Aug 5 and 6 for HF and Jersey, respectively), the number of days from first calving to conception (103, 83, and $85 \mathrm{~d}$ for $\mathrm{HF}$ and 91, 81, and $75 \mathrm{~d}$ for Jersey for first, second, and third lactations, respectively), or calving interval between the first and second lactations (381 and $373 \mathrm{~d}$ for $\mathrm{HF}$ and Jersey, respectively) and second and third lactations (369 and $365 \mathrm{~d}$ for HF and Jersey, respectively). Survival is defined as the number of productive lactations achieved by a cow. Pasture allowance or subsequent growth rate during either period did not impact heifer survival (Table 5). On average 88 and $73 \%$ of heifers survived to second and third lactations, respectively, and there was no difference between breeds.

\section{CONCLUSIONS}

Level of feeding during the first allometric growth phase (prepuberty) did not affect subsequent milk production in seasonal calving, grazing dairy cows reared to calve at 24 mo. However, it appears that the higher
BW at calving, resulting from accelerated growth rate prepuberty, might have offset any negative effect of accelerated growth rate during this period. Time to puberty was shortened at higher planes of nutrition, and differences in BW were evident until 51 mo. Level of feeding during the second allometric growth phase (postpuberty) was positively associated with first-lactation milk production, but milk production differences were not evident in subsequent lactations. Level of feeding pre- and postpuberty and BW at first calving did not affect subsequent reproductive performance or cow longevity, although the reproductive synchrony program might have masked potential negative effects at first breeding.

\section{ACKNOWLEDGMENTS}

The authors acknowledge the assistance of M. Meyer, Cornell University; the technical expertise of J. Lancaster and C. Leydon-Davis; the statistical expertise of B. Dow; and all of the help afforded them by No. 2 dairy staff, in particular J. Curtis and R. Thomson. The assistance of participating farmers-K. and G. Monks; J. and M. Fisher; B. Ritchie, R. and J. Myers, G. Hanna (Wallace Farms); A., J., and M. Mockford; D. and K. Nikora; D. and H. Parker; W. and L. Beaumont; and R., P., C., and R. Hancock-is gratefully acknowledged. The reproductive expertise of $\mathrm{D}$. Nation and the coordination of animal health programs by T. Day is especially appreciated. This work was funded by New Zealand dairy farmers through the Global Program research fund.

\section{REFERENCES}

Abeni, F., L. Calamari, L. Stefanini, and G. Pirlo. 2000. Effects of daily gain in pre-and postpubertal replacement dairy heifers on 
body condition score, body size, metabolic profile, and future milk production. J. Dairy Sci. 83:1468-1478.

Anon. 2004. Facial eczema-Zinc treatment, recipes and dose rates. Farm Fact 1-8. Dexcel Online. http://www.dexcel.co.nz/farmfacts/ view_farmfact.cfm?id=1_8. Accessed Oct. 10, 2004.

Bortone, E. J., J. L. Morrill, J. S. Stevenson, and A. M. Feyerherm. 1994. Growth of heifers fed 100 or $115 \%$ of National Research Council requirements to 1 year of age and then changed to another treatment. J. Dairy Sci. 77:270-277.

Buckley, F., P. Dillon, M. Rath, and R. F. Veerkamp. 2000. The relationship between genetic merit for yield and live weight, condition score, and energy balance of spring calving Holstein Friesian dairy cows on grass based systems of milk production. J. Dairy Sci. 83:1878-1886.

Capuco, A. V., J. J. Smith, D. R. Waldo, and C. E. Rexroad. 1995. Influence of prepubertal dietary regimen on mammary growth of Holstein heifers. J. Dairy Sci. 78:2709-2725.

Carson, A. F., A. R. C. Wylie, J. D. G. McEvoy, M. McCoy, and L. E. R. Dawson. 2000. The effects of plane of nutrition and diet type on metabolic hormone concentrations, growth and milk production in high genetic merit dairy replacement heifers. Anim. Sci. 70:349-362.

Choi, Y. J., I. K. Han, J. H. Woo, H. J. Lee, K. Jang, K. H. Myung, and Y. S. Kim. 1997. Compensatory growth in dairy heifers: The effect of a compensatory growth pattern on growth rate and lactation performance. J. Dairy Sci. 80:519-524.

Cliff, S. C., G. R. Morris, I. S. Hook, and K. L. Macmillan. 1995. Calving patterns in dairy heifers following single "set-time" inseminations and re-synchrony preceding second inseminations. Proc. NZ Soc. Anim. Prod. 55:70-71.

Cowen, R. T., P. O'Grady, and R. J. Moss. 1974. Relationship of age and liveweight at first calving to subsequent lactation yields of Friesian heifers grazing tropical pastures. Queensland J. Agric. Anim. Sci. 31:367-370.

Crichton, J. A., J. N. Aitken, and A. W. Boyne. 1960. The effect of plane of nutrition during rearing on growth, production, reproduction and health of dairy cattle. III. Milk production during three lactations. Anim. Prod. 2:159-168.

Crosse, S., and P. Gleeson. 1988. Rearing replacement heifers for the dairy herd. Pages 46-47 in Proc. Moorepark Dairy Farmers Conf, Fermoy, Co. Cork, Ireland. Teagasc, Dublin, Ireland.

Foldager, J., and K. Sejrsen. 1987. Research in Cattle Production Danish Status and Perspectives. Mammary Gland Development and Milk Production in Dairy Cows in Relation to Feeding and Hormone Manipulation During Rearing. Landhusholdningsselskabets Forlag, Tryk, Denmark.

Foldager, J., K. Sejrsen, and J. T. Sorensen. 1988. The effect of plane of nutrition on growth and feed utilization in RDM and SDM heifers-Revision of energy requirements for growth. (In Danish with English summary and subtitles.) Report 648, Natl. Inst. Anim. Sci., Foulum, Denmark.

Ford, J. A. and C. S. Park. 2001. Nutritionally directed compensatory growth enhances heifer development and lactation potential. J. Dairy Sci. 84:1669-1678.

Freeman, M. 1995. Your Heifers in the Balance. Rep. Dairy Res. Devel. Corp. Department of Primary Industry and Fisheries, Tasmania.

Gardner, R. W., J. D. Schuh, and L. G. Vargus. 1977. Accelerated growth and early breeding of Holstein heifers. J. Dairy Sci. 60:1941-1948.

Gaynor, P. J., D. R. Waldo, A. V. Capuco, R. A. Erdman, and L. W. Douglass. 1995. Effects of prepubertal growth rate and diet on lipid metabolism in lactating Holstein cows. J. Dairy Sci. 78:1534-1543.

Genstat V Committee. 1997. Genstat 5, Release 4.1, Reference Manual. Oxford University Press, Oxford, UK.

Harris, B. L. and E. S. Kolver. 2001. Review of Holsteinization on intensive pastoral dairy farming in New Zealand. J. Dairy Sci. 84(E. Suppl.):E56-E61.

Harrison, R. D., I. P. Reynolds, and W. Little. 1983. A quantitative analysis of mammary glands of dairy heifers reared at different rates of live weight gain. J. Dairy Res. 50:405-412.
Heinrichs, A. J. 1993. Raising dairy replacements to meet the needs of the 21st Century. J. Dairy Sci. 76:3179-3187.

Hoffman, P. C., N. M. Brehm, S. G. Price, and A. Prill-Adams. 1996. Effect of accelerated postpubertal growth and early calving on lactation performance of primiparous Holstein heifers. J. Dairy Sci. 79:2024-2031.

Hoffman, P. C. 1997. Optimum body size of Holstein replacement heifers. J. Anim. Sci. 75:836-845.

Holmes, C. W., I. M Brookes, D. J. Garrick, D. D. S. Mackenzie, T. J. Parkinson, and G. F. Wilson. 2002. Feeding and management of heifer replacements. Pages 119-128 in Milk Production From Pasture. Massey University Press, Palmerston North, New Zealand.

Ingvartsen, K. L., J. Foldager, J. B. Larsen, and V. Ostergaard. 1988. Growth and milk yield by Jersey reared at different planes of nutrition. (In Danish with English summary and subtitles.) Rep. 645 Natl. Inst. Anim. Sci., Copenhagen, Denmark.

Keown, J., and W. Everett. 1986. Effect of days carried calf, days dry and weight of first calf heifers on yield. J. Dairy Sci. 69:1891-1896.

Kerr, D., A. C. Bird, and I. K. Buchanan. 1985. Heifer liveweight influences lifetime production. Queensland Agric. J. 111:32-36.

Kolver, E. S. and L. D. Muller. 1998. Performance and nutrient intake of high producing Holstein cows consuming pasture or a total mixed ration. J. Dairy Sci. 81:1403-1411.

Kolver, E. S., J. R. Roche, M. J. de Veth, P. L. Thorne, and A. R. Napper. 2002. Total mixed rations versus pasture diets: Evidence for a genotype $\times$ diet interaction in dairy cow performance. Proc. NZ Soc. Anim. Prod. 62:246-251.

Lacasse, P., E. Block, L. A. Guilbault, and D. Petitclerc. 1993. Effect of plane of nutrition of dairy heifers before and during gestation on milk production, reproduction, and health. J. Dairy Sci. 76:3420-3427.

Lammers, B. P., A. J. Heinrichs, and R. S. Kensinger. 1999. The effects of accelerated growth rates and estrogen implants in prepubertal Holstein heifers on estimates of mammary development and subsequent reproduction and milk production. J. Dairy Sci. 82:1753-1764.

Lean, I. 1994. Calf to cow - Care and profit. Tech. Bull. Smith Kline Beecham Anim. Health, Sydney, Australia.

Little, W. and R. M. Kay. 1979. The effects of rapid rearing and early calving on the subsequent performance of dairy heifers. Anim. Prod. 29:131-142.

Macdonald, K. A. and J. R. Roche. 2004. Condition Scoring Made Easy. Condition Scoring Dairy Herds. 1st ed. Dexcel Ltd., Hamilton, New Zealand.

McLean, D. M. and M. Freeman. 1996. Benefits from better grown heifers. Proc. Aust. Soc. Anim. Prod. 21:72-75.

Meyer, M. J., A. V. Capuco, and M. E. Van Amburgh. 2004. Effects of energy intake and time to puberty on mammary growth of prepubertal Holstein heifers. J. Dairy Sci. 87(Suppl. 1):275. (Abstr.)

National Research Council. 2001. Pages 234-243 in Nutrient Requirements of Dairy Cattle. 7th rev. ed. Natl. Acad. Sci., Washington, DC.

Niezen, J. H., D. R. Grieve, B. W. Mcbride, and J. H. Burton. 1996. Effect of plane of nutrition before and after 200 kilograms of body weight on mammary development of prepubertal Holstein heifers. J. Dairy Sci. 79:1255-1260.

O'Donovan, M., P. Dilon, M. Rath, and G. Stakelum. 2002. A comparison of four methods of herbage mass estimation. Irish J. Agric. Food Res. 41:17-27.

Park, C. S., M. G. Baik, W. L. Keller, I. E. Berg, and G. M. Erickson. 1989. Role of compensatory growth in lactation: A stair-step nutrient regimen modulates differentiation and lactation of bovine mammary gland. Growth Dev. Aging 53:159-166.

Park, C. S., R. B. Danielson, B. S. Kreft, S. H. Kim, Y. S. Moon, and W. L. Keller. 1998. Nutritionally directed compensatory growth and effects on lactation potential of developing heifers. J. Dairy Sci. 81:243-249.

Peri, I., A. Gertler, I. Bruckental, and H. Barash. 1993. The effect of manipulation in energy allowance during the rearing period of 
heifers on hormone concentrations and milk production in first lactation cows. J. Dairy Sci. 76:742-751.

Pirlo, G., M. Capelletti, and G. Marchetto. 1997. Effects of energy and protein allowances in the diets of prepubertal heifers on growth and milk production. J. Dairy Sci. 80:730-739.

Prior, R. L. and D. B. Laster. 1979. Development of the bovine fetus. J. Anim. Sci. 48:1546-1553.

Radcliff, R. P., M. J. Vandehaar, L. T. Chapin, T. E. Pilbeam, D. K. Beede, E. P. Stanisiewski, and H. A. Tucker. 2000. Effects of diet and injection of bovine somatotropin on prepubertal growth and first lactation milk yields of Holstein cows. J. Dairy Sci. 83:23-29.

Roche, J. R., P. G. Dillon, C. R. Stockdale, L. H. Baumgard, and M. J VanBaale. 2004. Relationships among international body condition scoring systems. J. Dairy Sci. 87:3076-3079.

Roche, J. R., J. Morton, and E. S. Kolver. 2002. Sulfur and chlorine play a non-acid base role in periparturient calcium homeostasis. J. Dairy Sci. 85:3444-3453.

Sejrsen, K., J. Foldager, M. T. Sorensen, R. M. Akers, and D. E. Bauman. 1986. Effect of exogenous bovine somatotropin on pubertal mammary development in heifers. J. Dairy Sci. 69:1528-1535.

Sejrsen, K., J. T. Huber, and H. A. Tucker. 1983. Influence of amount fed on hormone concentrations and their relationship to mammary growth in heifers. J. Dairy Sci. 66:845-855.

Sejrsen, K., and S. Purup. 1997. Influence of prepubertal feeding level on milk yield potential of dairy heifers: A review. J. Anim. Sci. 75:828-835.

Silva, L. F. P., M. J. VandeHaar, B. K. Whitlock, R. P. Radcliff, and H. A. Tucker. 2002. Short communication: Relationship between body growth and mammary development in dairy heifers. J. Dairy Sci. 85:2600-2602.

Stewart, J. A. and J. W. Taylor. 1990. Larger size or increased body condition for increased first lactation milk production in dairy heifers. Proc. Aust. Soc. Anim. Prod. 18:376-379.

Thomas, G. W. and F. J. Mickan. 1987. Effect of heifer size at mating and calving on milk production during first lactation. Aust. J. Exp. Agric. 27:481-483.

Thorne, P. L., J. G. Jago, E. S. Kolver, and J. R. Roche. 2003. Diet and genotype affect feeding behaviour of Holstein-Friesian dairy cows during late lactation. Proc. NZ Soc. Anim. Prod. 63:124-127.

Valentine, S. C., R. C. Dobos, P. A. Lewis, B. D. Bartsch, and R. B. Wickes. 1987. Effect of liveweight gain before or during pregnancy on mammary gland development and subsequent milk production of Australian Holstein-Friesian heifers. Aust. J. Exp. Agric. 27:195-205.

Van Amburgh, M. E., D. M. Galton, D. E. Bauman, R. W. Everett, D. G. Fox, and H. N. Erb. 1998. Effects of three pubertal body growth rates on performance of Holstein heifers during first lactation. J. Dairy Sci. 81:527-538.

Van der Waaij, E. H., P. J. B. Galesloot, and D. J. Garrick. 1997. Some relationships between weights of growing heifers and their subsequent lactation performances. NZ J. Agric. Res. 40:87-92.

Wildman, E. E., G. M. Jones, P. E. Wagner, R. L. Boman, H. F. Troutt, Jr., and T. N. Lesch. 1982. A dairy cow body condition scoring system and its relationship to selected production characteristics. J. Dairy Sci. 65:495-501. 